\title{
Supreme Audit Institutions in a High-impact Context \\ A Comparative Analysis of Performance Audit in Four Nordic Countries
}

Johnsen, Åge; Reichborn-Kjennerud, Kristin; Carrington, Thomas; Klarskov Jeppesen, Kim; Taro, Külli; Vakkuri, Jarmo

\section{Document Version}

Accepted author manuscript

\section{Published in:}

Financial Accountability \& Management

DOI:

10.1111/faam.12188

Publication date:

2019

\section{License \\ Unspecified}

Citation for published version (APA):

Johnsen, A., Reichborn-Kjennerud, K., Carrington, T., Klarskov Jeppesen, K., Taro, K., \& Vakkuri, J. (2019).

Supreme Audit Institutions in a High-impact Context: A Comparative Analysis of Performance Audit in Four

Nordic Countries. Financial Accountability \& Management, 35(2), 158-181. https://doi.org/10.1111/faam.12188

Link to publication in CBS Research Portal

\section{General rights}

Copyright and moral rights for the publications made accessible in the public portal are retained by the authors and/or other copyright owners and it is a condition of accessing publications that users recognise and abide by the legal requirements associated with these rights.

Take down policy

If you believe that this document breaches copyright please contact us (research.lib@cbs.dk) providing details, and we will remove access to the work immediately and investigate your claim. 


\title{
Supreme Audit Institutions in a High-impact Context: A Comparative Analysis of Performance Audit in Four Nordic Countries
}

\section{Age Johnsen, Kristin Reichborn-Kjennerud, Thomas Carrington, Kim Klarskov Jeppesen, Külli Taro, and Jarmo Vakkuri}

\author{
Journal article (Accepted manuscript*)
}

\section{Please cite this article as:}

Johnsen, A., Reichborn-Kjennerud, K., Carrington, T., Klarskov Jeppesen, K., Taro, K., \& Vakkuri, J. (2019). Supreme Audit Institutions in a High-impact Context: A Comparative Analysis of Performance Audit in Four

Nordic Countries. Financial Accountability \& Management, 35(2), 158-181. https://doi.org/10.1111/faam.12188

This is the peer reviewed version of the article, which has been published in final form at DOI: https://doi.org/10.1111/faam.12188

This article may be used for non-commercial purposes in accordance with Wiley Terms and Conditions for Self-Archiving

* This version of the article has been accepted for publication and undergone full peer review but has not been through the copyediting, typesetting, pagination and proofreading process, which may lead to differences between this version and the publisher's final version AKA Version of Record. 


\section{Supreme audit institutions in a high-impact context: A comparative analysis of performance audit in four Nordic countries}

Accepted for publication 18.12.2018 Financial Accountability and Management. https://doi.org/10.1111/faam.12188

28.12.2018 (11,173 words in main text including references)

Åge Johnsen*, professor, Oslo Business School, Oslo Metropolitan University, Norway

Kristin Reichborn-Kjennerud, senior researcher, Work Research Institute, Oslo Metropolitan University, Norway

Thomas Carrington, assistant professor, Stockholm Business School, Stockholm University, Sweden

Kim Klarskov Jeppesen, professor, Copenhagen Business School, Denmark

Külli Taro, ph.d., Ragnar Nurkse School of Innovation and Governance, Tallinn University of Technology, Estonia

Jarmo Vakkuri, professor, Faculty of Management, Tampere University, Finland

Running head: Supreme audit institutions in a high-impact context

*Address for correspondence: Åge Johnsen, Oslo Business School, Faculty of Social Sciences, Oslo Metropolitan University, P.O. Box 4 St. Olavs plass, NO-0130 Oslo, Norway. Email: aage.johnsen@oslomet.no

Acknowledgements: This article is part of the project entitled 'The influence of performance audit on public administration and politics: A comparative study of the Nordic Supreme Audit Institutions'. The project is financed by a research grant from the Joint Committee for Nordic Research Councils in the Humanities and Social Sciences (NOS-HS), project number 219574. The authors acknowledge the constructive comments we received when earlier versions of the article were presented for the European Group for Public Administration (EGPA) Annual Conference, Permanent Study Group XII Public Sector Financial Management, 26-28 August 2015, Toulouse; for the 1st Nordic State Audit Conference, Lund, 6 April 2016; for the 9th International EIASM Public Sector Conference, Lisbon, 6-8 September 2016; for the SCANCOR Seminar, Stanford University, 18 July 2017, and at a seminar for Queen's University of Belfast Management School, 13 April 2018. Finally, we acknowledge the constructive comments from the reviewers. 


\title{
Supreme audit institutions in a high-impact context: A comparative analysis of performance audit in four Nordic countries
}

\begin{abstract}
This article analyses survey data regarding the impact of supreme audit institutions' (SAls) performance audit on public administration in four Nordic countries. Regression analysis with pooled data from Denmark, Finland, Norway and Sweden indicates that performance audits have positive impacts on usefulness, changes, improvements and, to some extent, accountability, as perceived by auditees who have experienced the audits. The results show that some of the factors that earlier research found important for the impact of performance audits in some countries were insignificant for all the four Nordic countries, but that SAIs' legitimacy, audit quality, and consequences of media attention were important factors.
\end{abstract}

Keywords: Democratic accountability, government, improvement, performance audit, public management reforms 


\section{Introduction}

The quality of government is important for many aspects of society, such as social, economic and political outcomes, and predictability and impartiality are especially important for good governance (Rothstein, 2011). This appreciation for the quality of government has been reinvigorated by the works of Fukuyama (2015), who argued that the administrative capacities of states to deliver public goods and services are vital for the quality of governance. Some countries, particularly Northern European and Nordic countries, consistently score high on measures for the quality of government, economic development, equality, welfare and trust. Fukuyama even stated that 'getting to Denmark' should be an important aim for the public policy of many countries and governments.

Supreme audit institutions (SAIs) and their performance audits are assumed to be important for the quality of government. There is a long history of audits in government being used to make the public sector efficient, effective, and accountable, and almost all countries today have SAls. However, this practice is based on assertions of a positive impact on public administration and society, but without much empirical evidence.

The Nordic countries have a relatively long history of audits in government, with some countries having mandated governmental audits in their constitutions since the early 1800s. The development of audits in government in this region has closely followed the general development in public administration in many OECD countries after the Second World War, and some of the Nordic countries have, since the 1960s, been frontrunners in developing and using performance audit in government (Richardson \& Kindblad, 1983).

Prior research has not identified any significant impact that the organisation of the SAls has had on economic effects such fiscal policy, government efficiency or productivity, except for a negative relationship with corruption for those countries that use a court (Napoleonic) model (Blume and Voigt, 2017). Some studies have indicated that performance audits work well in some of the Nordic countries (Reichborn-Kjennerud, 2013; Reichborn-Kjennerud \& Johnsen, 2018). Another study indicated that the accountability regime with SAls that are organised with the board (collegiate) or Westminster model, as used in the Nordic and NorthEuropean countries, and conduct numerous performance audits, have higher impacts than the 'French' or other accountability regimes (Torres, Yetano \& Pina, 2016). Therefore, it is interesting to study how audit in government works in the high-trust, 'high-impact' Nordic context because this knowledge can be used for developing audit theory and improving practice.

Accordingly, the purposes of this article are to measure the impact of performance audits, empirically analyse possible determinants in the audit process that influence the impact, and explore common determinants across countries. The Nordic countries are especially interesting to study because the accountability regime that they employ seems to have high impact. The research questions are: (1) How do SAls' performance audits impact public administration? (2) What determines the positive performance audit impacts? By public administration, we mean ministries, agencies and other public-sector organisations that receive government funding and are therefore objects for the SAIs' audit. This article analyses 
several dimensions of the impact of SAIs' performance audits in four Nordic countries Denmark, Finland, Norway and Sweden - as perceived by civil servants who have experienced the performance audits in the audited organisations (auditees). We conduct this analysis by replicating a survey research instrument and pooling existing data from a Norwegian data set (Reichborn-Kjennerud, 2013) with new and comparable data from Denmark, Finland and Sweden. We identify SAls' legitimacy, audit quality, and consequences of media attention, as important determinants for several of the impacts.

This article contributes in several ways to theory and practice in public administration, audit and accountability. First, we analyse audit practices, particularly types of performance audits and design of the audit processes, in one of the accountability regimes currently associated with high impact. Second, we analyse several dimensions of impact and their determinants. Third, we probe the external validity of the 'mechanism' behind the earlier documented performance audit model in Norway, to a wider Nordic and international context. These determinants are important for developing a general theory for audit impact, as well as for improving practices, because some of these factors seem to be working in the Nordic context but not in some other contexts, and some factors that work in some countries do not work in other countries within the same context. Such issues may be subject to managerial discretion and organisational design, amenable for potentially developing 'best practices', and are therefore important for policy makers and managers. These issues are also interesting for future research in other contexts.

The remainder of the article is structured as follows. The second section reviews literature on the impact of performance audit in government. The third section presents the conceptual framework and hypotheses. The fourth section documents the research methods. The fifth section analyses the results. The sixth section discusses the results. The final section concludes.

\section{Literature review}

Until the 1970s, public administration was preoccupied with public policy and 'who gets what, when, and how', and emphasised planning and budgeting. The attention was predominantly on input. Thus, governmental audit institutions traditionally emphasised accountability, controlling whether accounts adhered to standards and activities complied with rules (Brown \& Craft, 1980). During the 1970s and early 1980s, many countries experienced extensive growth in the size and budgets of the public sector, and many countries also encountered fiscal imbalances (Lonsdale, 2000). With the rise of performance movements and especially evaluation in the 1960s and new public management (NPM) in the 1980s, many countries developed SAls and expanded the role of auditors as external controllers of the public administration (Put \& Bouckaert, 2011; White \& Hollingsworth, 1999). The SAls have subsequently taken on roles as judges, public accountants and evaluators with a mandate to assess whether the public administration works economically, efficiently, effectively and transparently, and auditors have sometimes also taken roles as consultants and given advice for implementing improvements (Pollitt et al., 1999). This evaluation activity, which places 
more attention on the system as a whole and the output of government, is called performance audit (other names include comprehensive audit, effectiveness audit, programme audit, and value for money (VFM) audit) (Barzelay, 1997). The names illustrate the purpose of assessing performance as well as accountability in the public sector, congruent with the NPM-focus on managing performance, delegating and giving freedom to subordinate entities, but controlling their results after the fact. With this new accountability regime, the question arises as to whether SAls and performance audits have impact. However, the problem, both for theory and practice, is that audit impacts are contested and their determinants are largely unknown.

The impact of performance audit can be defined as 'a wide range of direct or indirect, desired or undesired, influences that evaluations can exert' on some targeted objective (Van Loocke \& Put, 2011, p. 176). The question of impact is investigated and answered differently in at least three 'communities': the legislative and professional community, the critical accounting community, and the wider social science community.

Based on professional advice, legislators typically assume that audit has positive impacts and therefore often mandate audit. In the early stages of adopting performance audit in government, some legislators held that this activity was useful. For example, based on a case study of some most and least implemented performance audit reports in a group of US states, it was argued that:

Clearly, much of the work was used in an impressive way and led to specific changes and improvements in governmental operations, probably as a result of the highly pragmatic and utilitarian orientation of the work. (...) What emerge is not a picture of auditors and evaluators with startling new information, overpowering everyone with their skills and facts, and this leading all others to change. The picture, instead, is one of the auditors and evaluators revealing to legislative and executive officials what they suspected but did not know for certain, or what they already knew but could not document. (Brown \& Craft, 1980, p. 261)

Based on the assumption that audit and evaluation is useful, almost all countries today have SAls, and some have also mandated performance audit in government. In an early international review and comparison of performance audits in six countries in the early 1980s, Glynn (1985) found that Canada was the first country to adopt performance auditing in the 1970s. Sweden became the first European country to formally adopt performance audits, but there were few performance audit activities in the member countries of the EEC at that time. In the UK, the Parliament passed the National Audit Act in 1983 and established the National Audit Office (NAO) reporting to the Public Accounts Committee (PAC) in Parliament (Garrett, 1986). While the audit reports attracted widespread debate in parliaments, the design of Glynn's (1985) comparative study was based on document studies and therefore could not provide evidence about what actually happened in practice.

In the academic community, especially among critical scholars, the question of whether audits, in practice, contribute to a more efficient and effective public sector or are merely 
verification rituals that produce comfort in an 'audit society' has been debated since the mid1990s (Lapsley, 2009; Lægreid, 2014; Power, 1997, 2003). Much of the research and discussion on this matter has often centred on the impact of the audit society on processes and organisational behaviour; for example, on making things auditable. This research has, to a lesser degree, attempted to measure impacts in a wider societal and political context.

In other parts of the social science community, however, a number of empirical studies of the impact of audit on government have been conducted since the 1980s. Blume and Voigt (2007) conducted a cross-country assessment of the economic effects of the SAls' organisational structure, such as independence and mandate, using indicators for fiscal policy, government effectiveness and total factor productivity. Based on data from the 1990s and early 2000s and controlling for press freedom, party competition, federalism, and independent judicial system, they found no significant relationships, except that the perceived level of corruption was higher in countries with a court model for their SAls. Almost all countries have SAls, so it is not possible to assess the effects of SAls in comparison to countries without SAls. Therefore, SAls may have few effects or they may have important effects but with a structure, except for the court model, that does not seem to be important. Since the 1990s there has been extensive co-operation between SAls, for example through the International Organization of Supreme Audit Institutions (INTOSAI), to strengthen the audit institutions and develop audit guidelines and standards (for example ISSAI 3000, 3200), which may have improved the performance of the SAIs. Moreover, Blume and Voigt (2007) did not study performance audits in particular.

Van Loocke and Put (2011) explored the issue of the impacts of performance audit on government, and identified and reviewed 14 such empirical studies from 1980 to 2008 . They advised going beyond the often-used indicators for measuring impact that the auditors themselves employ to gauge impact, such as the percentage of recommendations implemented by the auditee and cost savings in government. The percentage of recommendations implemented does not necessarily say much about impact relative to potential impact, and the audits may have more impacts than cost savings; for example, enhancing learning, transparency and accountability. Moreover, Van Loocke and Put discussed different conceptualisations of impact and their measurability. Finally, they replicated a research design developed by Morin (2001) in Canada, in a Dutch case study in order to assess the impact of performance audit beyond the Canadian context. Van Loocke and Put (2011) concluded that Morin's (2001) findings were still valid, in that performance audit has an impact, but this impact may be modest.

Since Van Loocke and Put (2011) conducted their review, several other empirical impact studies have been published, including Morin (2010, 2014), Raudla, Agu, Taro and Douglas (2016), Reichborn-Kjennerud (2013), Reichborn-Kjennerud and Johnsen (2018), and Torres et al. (2016). These studies indicate different levels of impacts, from relatively low impact in countries using no systematic or a French (court model) accountability regime (Morin, 2010), to modest impact in Canada (Morin, 2014) and Estonia (Raudla et al., 2016), and high impact in countries using an Anglo-American (UK-Nordic) (Reichborn-Kjennerud, 2013; Reichborn- 
Kjennerud \& Johnsen, 2018) or Germanic way (Torres et al., 2016). What seems to determine the positive impacts - that is, that the audits result in actions being taken - is the presence of a legal mandate for the performance audit. In addition, as Torres et al. (2016) found in their comparative study, important determinants of a positive impact of the Anglo-American and Germanic way are, respectively, that the auditees take actions based on the audit recommendations and that the auditors conduct following-up processes, and that the parliaments discuss the audit and implement changes in reforms. In both a 'modest-impact' country such as Estonia (Raudla et al., 2016) and a 'high-impact' country such as Norway (Reichborn-Kjennerud, 2013; Reichborn-Kjennerud \& Johnsen, 2018), the impacts were determined by external pressure from media and signals from the political leadership. In Canada, by contrast, media did not seem to determine impact, conceptualised as contributing to change in the public administration (Morin, 2014). The auditees' existing plans for making changes and their assessment of the audits' potential for making improvements were determinants for making changes in Norway, but not in Estonia. In Norway, the administrative level of the auditees also determined the tendency to make changes. Interestingly, in Estonia, where the performance audits were not used much for holding the minister to account and did not produce many changes in the audited agencies, the performance audits were still found to be both useful and to contribute to improving operations (Raudla et al., 2016).

Despite all these studies, the issue of impacts of performance audit remains underresearched. There is no general accepted theory on the dimensions of impact, including factors that determine high impacts. Therefore, empirical studies of the impact of performance audits on public administration need to consider several dimensions of impact, and their determinants, and how impacts and determinants vary within as well as between different contexts.

\section{Conceptual Framework and Hypotheses}

Agency theory is a common theoretical framework for analysing accountability and effectiveness in government (Moe, 1997). However, there are several sets of principal-agent relationships involved in governmental audit (Streim, 1997). First, the voters as principal(s) elect representatives to parliaments as their agents. Second, the parliament acts as principal for the government. Third, the government is principal for the public administration. Fourth, among other measures, the parliaments as principals ensure that their policies are implemented in an accountable, efficient and effective manner by employing auditors as their agents who verify the government's accounts and assess the government's performance. In order to avoid collusion between the auditors and the government or undue influence, and to ensure relevant and high-quality audits, the legislators often mandate the audit and establish independent auditors (SAIs).

Agency theory may be used as a theoretical point of departure. However, auditing is much more than a simple, linear process where the auditor report to parliament, which then makes public policy and public administration change for the better on behalf of the electorate. First, while the parliament may be seen as the most important principal, representative 
democracies consist of many parties and stakeholders. Hence, in practice, the SAls may have to relate to several stakeholders even though the SAls may formally report to one public accountability committee. Second, the SAls may be seen as agents that are financed by and reporting to parliament, but the SAls are, by definition, independent. The SAls are often free to choose what to audit and select methods by their own choice and following professional standards (ISSAI 3000, 3200); for example, how to follow up on suggestions from whistleblowers, the media or the public in fire alarm-like audits or establish internal routines for selecting interesting topics for audits in police patrol-like monitoring (McCubbins \& Schwartz, 1984) in the SAls' strategic planning process. Third, the parliaments may formally have only one SAI, but in practice there may be many organisations that monitor, inspect, audit, and evaluate the government. Fourth, given that the parliaments in themselves are complex systems and political institutions, the audit information may or may not be utilised effectively in holding the government accountable. Fifth, the governments are also complex and institutionalised systems that are comprised of many stakeholders with self-interests and subject to bounded rationality. Therefore, the accountability regime in government may better be conceptualised as an institutionalised, complex, multi-principal, multi-agent system than as a simple principal-agent relationship. These distinctions of the audit and evaluation in government in general may exemplify that many factors influence both the production and utilisation of the audit information in government. Therefore, we now turn to the evaluation literature in order to first conceptualise the impact of performance audit and then to develop hypotheses on determinants for the performance audit impact.

Weiss (1979) and Nutley and Webb (2000) distinguished several dimensions of impact of research information such as evaluation. First, the evaluation may give rise to instrumental use of the information, which assumes a process whereby the information leads to new knowledge and knowledge to policy. Second, the evaluation may also give rise to conceptual impact. Conceptual impact means that knowledge changes different actors' conceptions of problems, solutions and effects of public policy, and that these altered conceptions gradually permeate policy. Thus, audit information may act as 'sand in the oyster'. The information seemingly has little impact in the short run but materialises in the longer run. By providing new knowledge, the impact of the performance audit may also resemble organisational learning, meaning that the information gives new insights into the potential for action, although organisational learning on a conceptual level does not require any specific changes or material improvement to take place (Huber, 1991). Third, the evaluation may give rise to interactive impacts, which means that the audit information is used by several groups of participants that interact partly by competition and partly by co-operation in using the information in the decision-making process. Fourth, the use of audits may be part of a complex process that also involves information sources other than the audit and existing insights and bias, such as political-legitimising use and tactical use. Political-legitimising use means that knowledge is an asset in a political debate (Feldman \& March, 1981), while tactical use means that knowledge is used to influence a decision-making process. Therefore, this use of the information may provide new knowledge that someone regards as useful; for example, the 
opposition for holding a minister to account, and for the government in arguing for policy changes and furthering improvements. Finally, the evaluation information may facilitate enlightenment in that the public is better informed about public policies and their outcomes. However, these impacts overlap to some extent (Van Loocke \& Put, 2011).

Figure 1 here

Figure 1 outlines our conceptual framework, which incorporates the dimensions outlined above. The performance audits may be perceived as useful in that they provide new knowledge in some respect for some actors. This knowledge may be used for holding someone to account and making changes that may or may not result in improvements for someone or something in society. The four dimensions conceptualise impacts on different levels. Usefulness is perceived on the individual level. Holding to account concerns political systems, often involving ministerial organisations. Change and improvement pertain to activities, services and organisations, possibly affecting value chains and policies. Having conceptualised four dimensions of impact, we now turn to identifying possible important determinants, particularly traits with different actors in the principal-agent relationships and how the SAls design the performance audits.

SAls are among several institutions that provide monitoring information to many stakeholders in a political context. In order to be trusted by different stakeholders with different interests, the SAls need legitimacy (Funnell, 2015; Guthrie \& Parker, 1999; Jacobs, 1998; Lonsdale, 2008). This legitimacy may stem from avoiding taking a political role, being unpartisan, and selecting 'interesting' topics for audit; in short, being independent, relevant and trustworthy (Triantafillou, 2017). Based on Reichborn-Kjennerud (2013) (her hypothesis 2), we expect that SAls that are perceived as having much legitimacy will produce audit reports that are perceived as useful $(\mathrm{H} 1)$.

Performance audit is one information source that the SAls provide for their principals, typically the parliaments and their public accounts committees, in order for the principals to better monitor and control their agents (the public administration). Performance audits may be negotiated and designed differently and oriented towards scrutinising compliance to rules, activities and results (Basu, Dirsmith \& Gupta 1999). The type of performance audits may be chosen depending on many factors, such as the perceived problem, auditors' training, available resources for the audit, organisational strategy (Barzelay, 1997), dominant public management culture (Hood, 1998), or governance paradigm (Osborne, 2006). Much of the development of the SAls and their performance audit has been the result of new public management, with its emphasis on outcomes and effectiveness. Therefore, we expect that results-oriented audits were more useful for the auditees than activity- and complianceoriented audits ( $\mathrm{H} 2)$.

Civil servants have different tasks and responsibilities. Civil servants in ministries give advice, are close to government politicians who will be made responsible for the public policies, and may be involved in policy-making (Alford, Hartley, Yates, \& Hughes, 2017). Being 
close to their political principals, the ministerial civil servants are quite closely monitored by the political staff, and the ministerial civil servants also get to know their political principals' interests well. Therefore, the civil servants may often not find performance audits useful, which the opposition often use to criticise the minister or government. Reichborn-Kjennerud (2013) did not get support for the notion that civil servants in ministries find performance audits more useful than their colleagues in subordinate administrative levels (her hypotheses 4). On the other hand, civil servants in subordinate public administration bodies such as agencies and government-owned corporations are more remote from the political principals and have more decentralised tasks and responsibilities. Therefore, they need information on policy implementation and outcomes. Reichborn-Kjennerud and Johnsen (2018) found that, in Norway, subordinate bodies use the audit information for making changes more than ministries do (their hypothesis 5 ). Therefore, we expect that civil servants in subordinate bodies would find performance audits more useful $(\mathrm{H} 3)$ and make more changes $(\mathrm{H} 4)$ than civil servants in ministries.

Performance audit reports may be made public and accessible to the public administration as well as the public at large. Publication of the audit may provide an opportunity for the information to be used, but providing relevant and reliable information may, in itself, be inadequate in order for the information to be used, such as holding someone to account or making changes. Interest in the information, however, may give someone both the opportunity and motivation to use the information (Hood, 1995). Therefore, we expect that actors furthering their interests use the audits for holding ministers to account (H5).

There may be many well-prepared plans for making changes in the public administration, which for many reasons are not executed without external pressure. The publication of a performance audit from an external evaluator, with conclusions that corresponds to existing plans, may be found especially useful because such an event provides an opportunity to make a change where the motive already was present $(\mathrm{H} 6)$.

Some of the auditors and the routines employed, stemming from an accounting rather than an evaluation tradition, often use explicit standards or specific criteria in the assessments. The use of such criteria makes it feasible for the auditors to assess and give advice on the issue in question without being regarded as subjective and arbitrary. Therefore, in the audit process the auditors often use checklists and demand specific information, which may help the auditors in being as objective and systematic as they can, modelled after the accounting profession. Sometimes, however, the auditees see this procedure of being made auditable as formalistic and 'rigid' without adding value (Reichborn-Kjennerud \& Johnsen, 2011). Therefore, we expect that performance audits that are perceived as rigid are less useful than performance audits that are perceived as less rigid ( $\mathrm{H} 7)$.

Performance audits, unlike financial audits, are infrequent projects ('fire alarms') that can put a great deal of strain on the auditees. The auditees have to attend meetings, produce data, answer questions and comment on draft reports in order to make things auditable (Brown \& Craft, 1980; Keen, 1999; Power, 1996; Skærbæk, 2009). If the audit process has only been moderately demanding and the final reports produce substantial new knowledge for the 
auditees that outweighs the costs associated with producing the information, we expect that the auditees will be more likely to find the audit useful than auditees that experience a stressful audit process (H8).

When selecting topics and methods for the audit, the SAIs normally design the audit in such a way that the final report will contain material of interest regarding economy, efficiency and effectiveness, including equity. The auditors design their studies by searching for and selecting significant topics with risks and problems, which maximises the impact for society given the resource limitations in the SAI (ISSAI 3000). Therefore, there is a selection bias in performance audit of 'bad news'. When something is 'interesting' or 'significant' for risks and problems, it often means that someone could be held accountable for something and that some issue is substandard and could be improved. In practice, the audit may result in 'blaming and shaming' - for example, by holding a minister to account (Hood, 2007; Skærbæk \& Christensen, 2015) - which may be discomforting for the substandard auditee and responsible minister. In order to produce reliable and interesting audits and uphold high standards and integrity for their independence, it is important for the SAls to ensure good communication, both during the production of the audit (Roberts \& Pollitt, 1994; Keen, 1999) and in the dissemination of the audit results (Bringselius, 2014; González-Díaz et al., 2013). In a good communication process during the production of the audit, the auditees will be given due opportunities to provide reliable data and correct material errors in draft reports so that the final report is considered reliable, even though it might produce discomfort (Carrington \& Catasús, 2007). SAls pursuing the goal of change to improve public administration would likely emphasise working closely together with the auditees in order to get the auditees to psychologically 'own' the recommendations (Barzelay, 1997). Reichborn-Kjennerud (2013) found support for a positive relationship between the auditees agreeing with the audit criteria and being allowed to influence the audit process, with perceived usefulness in Norway (her hypothesis 11). Therefore, we expect that performance audits with good communication processes will lead to more changes (H9) than processes with poor communication.

Performance audits are designed in the SAIs' strategic plans after careful analysis of significant potential risks and problems in the public administration (ISSAI 3000). The feature of customised, almost 'tailor-made', performance audits requires that the auditors are highly skilled regarding audit methods and the policy area in question in order for the audits to provide new and relevant information that is useful. Therefore, quality may depend on the selection of object for audit, choice of methods, communication of the results in the report, and relevant advice. Reichborn-Kjennerud (2013) found support for these mechanisms explaining usefulness in Norway (her hypothesis 3); Raudla et al. (2016), in addition to a relationship with usefulness, also found support for an impact on making changes in Estonia (their hypotheses 2.2 and 3.2). Therefore, we expect performance audits that have high quality to be perceived as more useful $(\mathrm{H} 10)$ and make more changes $(\mathrm{H} 11)$ than low-quality audits.

The political agenda is often closely linked to what issues the media find interesting. Performance audits that provide information on potential risks and problems in the public 
administration are interesting for media. Attention from the media or interest organisations often puts pressure on ministers, which causes the public administration to act on the information. Information that is 'bad news' for one person could be good news for another; for example, because the information on risks and problems can be used by the opposition for questioning the government's ability to execute policies properly or for challenging some minister's integrity and accountability. Public administrations are complex systems that often handle difficult issues - 'wicked problems' - balancing the interests of a multitude of stakeholders including powerful internal actors, executing a large number of programmes, and utilising a large number of tools. Therefore, public administrations often operate in a delicate balance between opposing interests in different principal-agent relationships and between different political actors, many issues competing for attention, and scarce resources. This complexity and delicate balance makes it difficult to change public administrations (Metcalfe \& Richards, 1990; Wilson, 2000). External shocks, crises, and new external pressure can unsettle the balance and trigger processes for reform and change (Jones \& Baumgartner, 2005; Pollitt \& Bouckaert, 2011). When media find performance audits that document misconduct, misjudgement and improper use of public money, it could often be politically opportune to use this information for making changes or holding someone, often the minister in charge, to account. For example, Reichborn-Kjennerud (2013) found that media attention on the reports was related to holding ministers to account in Norway (her hypothesis 9). However, survey data and a case study showed that most of the reports received moderate attention from the media and the parliamentary control committee in the public debate (Reichborn-Kjennerud, 2014), possibly indicating that only some topics are politically salient. Raudla et al. (2016) only found partial support for media attention being important for performance audits having an impact on making changes in Estonia (their hypothesis 3.7). It is interesting to explore whether media attention was idiosyncratic to the Norwegian setting or is a relevant factor generally, at least in the Nordic countries. Therefore, we have formulated hypotheses in which we expect that performance audits that receive a lot of media attention, providing new external pressure, are used for holding someone to account (H12) and give the public administration impetus for change $(\mathrm{H} 13)$.

Table 6 presents the 13 hypotheses as well as the resulting empirical corroboration.

\section{Methods and Data}

\section{Population and Sample}

This study uses a most-similar case design (van Thiel, 2014) by choosing the relatively homogenous countries of Denmark, Finland, Norway and Sweden for the analysis. The logic for choosing this design is that if results from one country are reproduced in the other countries, then this replication strengthens the reliability and validity of the findings. Comparative research in public policy has some challenges, though. Engeli, Allison and Montpetit (2018) found that most of the comparative research in top-tier political science journals over an 18-year period addressed a limited number of mostly North American and Western European countries, including Denmark and Sweden. Our focal countries are also 
European countries, but albeit Finland has been used in comparative audit studies before (e.g. Pollitt et al., 1999), there have been few comparative studies of audit in the Nordic countries together. These countries are therefore interesting for comparative research and even more so given that the accountability regime in these countries seems to have high impact (Torres et al., 2016). Moreover, in order to strengthen generalisability of the results we employed large- $\mathrm{N}$ surveys for the data collection.

The Nordic countries are small, egalitarian, high-trust welfare states (Fukuyama, 2015; Rothstein, 2011). Despite many similar institutions, there are also some differences in the public administration and accountability regimes. The East Nordic administrative tradition in Sweden and Finland has a 'collegial model', and the West Nordic tradition in Denmark and Norway (and Iceland) has a 'ministerial model' (Öberg \& Wockelberg, 2016). The West Nordic public administration model is the most hierarchical system, has the largest ministries and least autonomous agencies, and the East Nordic model is the most decentralised system, has the smallest ministries and most autonomous agencies. Accordingly, ministries in the West Nordic administrative tradition may have more hierarchical reporting and monitoring capacity than their East Nordic counter parts. This means that external audit information could provide more novel, and therefore more useful, information in Finland and Sweden than in Denmark and Norway.

Some of the Nordic countries, such as Sweden, have had active national audit institutions conducting evaluations for many decades (Glynn, 1985; Lonsdale, 2000; Richardson \& Kindblad, 1983). The OECD mapped its member countries' policies for reviews and performance audits in 1996 and found that only 13 countries responded and 12 countries reported performance audit activities (Barzelay, 1997). Finland, Norway and Sweden were among the countries with the most active SAls in terms of performance auditing (Denmark did not respond to that mapping). INTOSAl surveyed its members in 2007 and concluded that probably fewer than 30 SAls had well-developed and stable approaches to performance audit work (Put \& Bouckaert, 2011). Therefore, at least three of the Nordic countries have had performance audits for a long time, making the Nordic countries suitable for empirical analysis of impacts.

Table 1 here

Table 1 shows that the countries share many political and administrative characteristics, such as being small and democratic countries and unitary states. The countries also differ on some institutional and economic aspects. In 2012, the populations of these countries ranged from 5 million inhabitants in Norway to 9.5 million in Sweden. The countries had both old and new national audit institutions, and have been differently affected by financial crises, the most recent in 2007.

Data Collection 
Our research started with pilot and focus group interviews with senior SAI managers and the auditors-general in the four countries in 2010. Some of the authors also have first-hand experience with audits and/or have been studying public sector audits and have had regular contact with public sector auditors for a long time. This information was used in the development of the data collection and analysis of the data.

There is no readily available administrative data on the impact of audits in public administration. Moreover, the impact of audits is multi-dimensional, and we wanted to explore impact on several dimensions simultaneously. Therefore, we decided to collect survey data with a questionnaire of civil servants who had experienced performance audits. The survey was developed based on adaptation of previously used survey questions in the literature, for example from Morin (2001). The survey was tested and the first data collection took place in Norway in 2012, covering the public institutions that had experienced governmental performance audits between 2005 and 2010. (See Reichborn-Kjennerud (2013) for an elaboration of the development of the original survey instrument.) The survey was subsequently translated to English and then to Danish, Finnish and Swedish. Given that Danish, Norwegian and Swedish are intelligible to most Scandinavians, and that many Finns speak Swedish, the Nordic researchers could also utilise the original Norwegian survey instrument in their adaptation of the survey. The data collection in the Denmark, Finland and Sweden took place in 2013-2014 and covered all performance audits carried out by the SAls between 2005 and 2012. (The survey instruments are available from the authors on request.) The time lapse between the conduct of the study in Norway and the subsequent studies in the other Nordic countries could have impacted on the findings. However, we have no indication of special incidents in the four countries potentially impacting the findings during our period of study. There was a public debate in Norway in 2012 regarding the rigidity and alleged attention to insignificant details in performance management in general and the political role of the auditor-general in Norway, and there was a scandal involving the top management of the Swedish National Audit Office in 2016, but these incidents happened after our period of study.

The targeted respondents were selected as those civil servants who had managed the audit in the audited bodies and had first-hand experience with the audit processes and reports. In each country, the organisations that had been the object of performance audit in the period of study were contacted and asked to provide contact information for the civil servants who were responsible for the handling of the performance audits.

Using perception data to measure complex phenomenon such as performance and impacts may be only one, limited, source of data but we avoided potential subjectivity bias by asking civil servants in the auditees about the auditors' activities and products, as well as how the audits subsequently were handled in the political system (Meier, Winter, O'Toole, Favero \& Andersen, 2015). Subjectivity bias could have posed a problem if we had instead asked, for example, members of parliaments or auditor staff to assess the work they had commissioned or conducted themselves. 
Table 2 here

Table 2 reports the targeted sample and the responding sample. In total, 643 of the targeted 1202 civil servants responded to the surveys, resulting in a response rate of 53 per cent. Finland's low response rate was largely due to the design of the survey that only accepted responses with answers to all questions. Moreover, the majority of the Finnish performance audits were evaluations using informants from both inside and outside publicsector organisations. These informants who experienced the performance audits may have changed affiliation after the audits and were often hard to reach as respondents for the Finnish survey, resulting in relatively few responses.

All of the questions on the respondents' perceptions used a five-point Likert-type scale ranging from 1 (to a very little extent/completely disagree) to 5 (to a very large extent/completely agree).

\section{Measurement}

Table 3 documents seven indexes constructed out of questions in the questionnaire, measuring different aspects of the audit process, as perceived by the civil servants.

\section{Table 3 here}

The 'legitimacy index' measures the civil servants' perception of the SAls' ability to contribute to improvement and prevention of corruption and mismanagement. The 'performance audit rigidity index' measures negative aspects of the performance audit report. The 'audit process strain index' measures how taxing the auditees experience the audit to be. The 'audit process communication index' measures the extent to which the audited civil servants feel that their comments have been taken into account in the performance audit process. The 'report quality index' measures different aspects of the quality of the performance audit report. The 'consequences of the media attention index' measures mechanisms that the media attention can involve, such as affecting the reputation of the audited entity, risk aversion, triggering debates, leading to political pressure from political opponents. The 'improvement index' measures the extent to which the civil servants could use the audit to make changes to systems that did not previously work well and whether policy areas that had previously been overlooked had gained increased attention. The indexes have been constructed as a mean of all the variables in the given index. The indexes' reliability (Cronbach's alpha) scores varied from 0.64 to 0.94 , with all above 0.6 and five of the seven indexes above 0.7 , indicating acceptable-to-good reliability for exploratory purposes (Hair, Anderson, Tatham, \& Black, 1992).

Two categorical independent variables have been converted into several dichotomous variables in the regression analysis. These are the country variable (with values for Denmark, Finland, Norway and Sweden) and the type of performance audit variable (with the values compliance-oriented, oriented to activities, and results-oriented). The categorisation of the 
audits as compliance-, activity- or results-oriented measured the scope of the audits. However, the scale of the audits could vary over time and between countries, which could confound the results. The annual number of performance audits (and major studies, which is a term used in Denmark) typically vary from 13 in Denmark to 30 in Sweden (Jeppesen et al., 2017), but there is also annual variation in the number of performance audits, for example ranging from 11 to 15 per year in the period 2005-2010 in Norway. Norway and complianceoriented audits are used as reference points coded 0 , and the other dichotomous variables have been coded 1 if the value is present and 0 if not.

\section{Dependent Variables}

Four dependent variables are proxies for the different dimensions of impact on the audited entities: perceived usefulness (conceptual impact), holding ministries and agencies accountable for their actions (political-legitimising and tactical use), making changes as a consequence of the assessments in the performance audit report (instrumental use), and improving operations in the audited entities (interactive impact, the performance audit report being just one source used to make improvements in the audited entity).

Usefulness was probed by the question: 'In general, to what extent did you think that the performance audit was useful?' This variable measures the potential for conceptual impact. The perception of the report as useful does not necessarily entail actual changes in the audited entity. However, if the civil servants perceive the report as useful, it may affect their reasoning and the way they think about their policy area.

Holding to account was probed by the question: 'To what extent do you think that the performance audit report was used to hold the ministry and agencies accountable for their actions?' This variable measures performance audit as an instrument of accountability, meaning whether or not members of parliament use the audit to hold the government to account for the way it has managed public money.

Change resulting from the performance audits was investigated by the question: 'To what extent did the audited entity make changes as a consequence of the assessments in the performance audit report?' This variable measures instrumental changes that the audited organisations made after the performance audit.

Improvement resulting from the performance audit was probed by the question: 'To what extent did the performance audit prompt improvements in your organisation?' This variable indicates a subtler link between the report and what comes after. The concept of 'improvement' is also political because what one group conceives as an improvement, another group might conceive differently (Boyne 2003). Opinions may even differ internally in the ministries and agencies.

\section{Independent Variables}

In addition to the indexes reported above, the independent variables included questions and statements about the auditees' category of administrative level ( $0=$ ministry, $1=$ subordinate body such as agency or government-owned enterprise), and Likert-type variables on the civil 
servants' perceptions regarding auditee interests, media attention, and existing plans. These were: 'To what extent do you agree that the performance audit has been used by different actors to further their own interests?', 'To what extent did the media show an interest in the performance audit?', and 'The performance audit suggested measures that the organisation was favourable of, so we would have made these changes anyway'.

\section{Control variables}

We included the civil servants' positional level (1=junior manager, 2=middle-level manager, or $3=$ senior manager), the civil servants' experience with the performance audits (number of performance audits), and the contribution to improvement index as control variables.

We expected that higher-ranking civil servants, due to their wider responsibilities for overall performance, would find the performance audits more useful than lower-ranking civil servants.

Experience with previous performance audits may be important in order for the civil servants to find the performance audits useful. Public administration is a complex business. SAls and performance audits are embedded in many institutional arrangements. Assessing the informational value of an audit report during its different stages of production may require knowledge of the policy area in question as well as research methods that the auditors use and the institutional arrangements in the public administration; this is something the civil servants may gain by increasing experience with audits.

In the regression model of usefulness, we include the index measuring contribution to improvement as a control variable.

\section{Common method bias and missing data}

Using the same research instrument for collecting self-reported data for both the independent and dependent variables may give rise to common source bias. Common source bias means that some variations in the data are shared across the variables due to same method used for collecting the data. Common source bias may pose problems, especially when the survey also probes questions on organisational performance, but there are remedies to deal with such problems (George \& Pandey, 2017). We have asked the respondents questions about traits regarding the auditors' activities and products, as well as the auditee's actions, and not the performance of the respondents' organisation. Moreover, we have developed scales, were feasible, and tested the reliability of the scales. Finally, we conducted a Harman's one-factor test for the 44 items used in the analysis. One factor explained less than 29 per cent of the total variance, which is well below the common threshold of 50 per cent for indicating common source bias problems. The Harman one-factor test is not conclusive (Jakobsen \& Jensen, 2015), but the results indicate no major problem with commons source bias in our data.

Due to the high percentage of missing data, we tested for bias by performing Little's Missing Completely at Random (MCAR) test with the 24 variables used in the analysis. The test produced a non-significant result at the $p=.05$ level (chi-square=328,018, $d f=293$, sign. $=.078$ ), 
but significant at the $p=.10$ level, so we cannot rule out bias in the missing data. Accordingly, we have avoided replacing missing values and instead utilised as many responses as possible by using 'listwise' deletion of cases in each of the regression models.

\section{Results}

Table 4 documents descriptive statistics and the bivariate correlation coefficients for the variables in the analysis. The usable sample consisted of 167 cases for all the 24 variables used in the analysis. Cases from Denmark, Finland, Norway, and Sweden comprised 28, 38, 23, and 11 per cent of the responses in the usable sample, respectively. Fifty-six per cent of the respondents worked in subordinate bodes such as agencies and government-owned corporations, most had middle management positions, and the mean number of performance audits experienced was 3.6. The usable sample had 18 per cent activity-oriented, 42 per cent compliance-oriented and 40 per cent results-oriented performance audits. The civil servants found that these performance audits on average were useful (3.28), resulted in changes (3.22), and led to some improvements (3.08), but that they were little used for holding the minister to account (2.69).

Table 4 here

In order to answer the research questions, we conducted multiple regression analyses in which we purported to identify determinants for the impacts of the performance audit on public administration, as well as different impacts between the countries. All correlations between the independent variables were no higher than 0.70 , and all variance inflation indexes (VIF) were less than 5 (see Table 5), which means that there were no potential problems related to multicollinearity in the regression analyses.

Table 5 reports two regression models for each of the four dependent variables, one model without 'dummy' variables for the countries and one model with these variables included. Only significant relationships in the models are pointed out. All eight regression models were significant, as assessed by the significance levels of the F-values, but only the models for usefulness (model I and II) and improvement (model VII and VIII) explained a substantial part of the variance (with the highest adjusted R2 being .65 and .23, respectively).

Table 5 here

Model II explained usefulness and controlled for the audits' perceived contribution to improvement. In this model, performance audits that were performed by SAls with much legitimacy $(r=.32$, significant at the $p=.01$-level), having little rigidity $(r=-.15$, significant at the $p=.05$-level), having high quality ( $r=.47$, significant at the $p=.01$-level), and contributing to improvement ( $r=.38$, significant at the $p=.01$-level) were perceived as being more useful than other audits. The performance audits were also perceived as more useful in Sweden than in the other countries ( $r=.31$, significant at the $p=.10$-level). 
Model IV, explaining accountability, showed that performance audits subject to many consequences from media attention (including the opposition's pressure on the minister and/or administration) ( $r=.38$, significant at the $p=.01$-level) were used more for holding the minister to account than other audits, and respondents in Sweden ( $r=.72$, significant at the $p=.05$-level) perceived the audits to be used more for accountability than in Norway.

Model VI showed that the SAls' legitimacy ( $r=.17$, significant at the $p=.10$-level), the audit process strain $(r=.21$, significant at the $p=.10$-level), and the audit reports' quality $(r=.37$, significant at the $p=.05$-level) were positively related to a perception of the auditees making changes, while results-oriented audits ( $r=-.38$, significant at the $p=.10$-level) were negatively related to this perception. Interestingly, a stressful audit process was perceived to be positively related to changes ( $r=.21$, significant at the $p=.10$-level).

Model VIII showed that the SAls' legitimacy ( $r=.36$, significant at the $p=.01$-level) were positively related to a perception of prompting improvements but that performance audits in Denmark ( $r=-.48$, significant at the $p=.05$-level) and Finland $(r=-.61$, significant at the $p=.01$ level) were perceived to have less impact on improvement than in Norway.

Table 6 here

Table 6 summarises the results from the regression analyses and compares these results with similar results from other studies that have employed the same research instrument. For comparison, see Raudla et al. (2016), Table 7; Reichborn-Kjennerud (2013), Table 5; and Reichborn-Kjennerud \& Johnsen (2018), Table 4. Four of the 13 hypotheses were corroborated. SAls' legitimacy is significant for usefulness (hypothesis 1), audit quality is significant for usefulness (hypothesis 10) and for making changes (hypothesis 11), and consequences of media attention is significant for the information being perceived as used for holding someone to account (hypothesis 12).

\section{Discussion}

The results indicate that some of the findings on performance audit impact determinants found in the literature in single case/country studies - for example, in the Estonian and Norwegian cases - may have low generalisability in a wider context. This highlights the contribution of conducting replication as well as comparative studies, as does the present article. However, some factors seem to be important determinants for positive impacts in the Nordic accountability regime.

What seemed to have enhanced the civil servants' perception of the performance audit reports as useful was the perception of the legitimacy of the SAI as an institution that reduces and prevents mismanagement and corruption, which increased the civil servants' perception of the reports as useful. Audit report quality was also an important factor explaining usefulness. If the civil servants perceived the report as balanced and of high quality, and perceived the audit process as not being rigid, this enhanced their perception of the report as useful. Last but not least, the degree to which the audits were perceived as contributing to 
improvements - understood as the extent to which the civil servants could use the audit to improve systems and also if policy areas that previously were overlooked had gained increased attention - was also important.

The reports were used for holding the minister to account, to a larger extent, when the consequences of media attention were high, as also found in Estonia (Raudla et al., 2016). If a political debate was initiated by the media, if the minister or the administration was pressured by political opponents as a consequence, if the report affected the organisations' reputation or if the organisation became overly prudent, then the use of the audits for holding the ministry or agency to account increased. Many SAls use the communication strategy of openness and dissemination of audit results, for instance through press releases and press conferences that result in media attention (González-Díaz, García-Fernández, \& López-Díaz, 2013). Media attention alone is not sufficient, but the consequences of media attention are important. This points to the need to conceptualise audits as more than just linear, instrumental processes where the audit information would automatically change the parliament's or the government's behaviour. Democratic accountability and monitoring possibly need more than attention from administrative reporting in hierarchical relationships alone, and should be complemented with transparency, media attention, and parliamentary scrutiny, as more advanced agency theory models depict (Streim, 1993).

The perceived quality of the report - and, to some extent, perhaps also a straining audit process and the perceived legitimacy of the SAI as an institution - increased the perception that changes occur after the performance audit.

The legitimacy of the SAI was equally important for the civil servants' tendency to use the report to make improvement in their organisation, but the causal relationship may well be that impacts from the performance audits affect the SAIs' perceived legitimacy.

The regression analyses also revealed some different impacts between the countries. Sweden had a significant impact on using the audit reports for holding the minister to account. One explanation is that in Sweden, which has a system of relatively small ministries and autonomous agencies, the performance audits were used much for accountability, which is otherwise demanding in the East Nordic public administration model, which emphasises collegiate accountability.

In Denmark and Finland, the performance audits seemed to have had a low impact on improvement. In Denmark, where the performance audit approach is partly focused on checking compliance with acknowledged standards of public sector management (Jeppesen et al. 2017), civil servants perceived the performance audit as having little impact on making improvement. In Finland, which has an evaluation-oriented SAl that does not emphasise giving advice, the civil servants found the audits least likely to lead to improvement. The purpose of its performance audits is to evaluate common themes across different ministries and sectors of government, often with informants on effects from different tiers of government and sectors in society. This implies that the Finnish performance audits are not designed to hold someone to account or to make imminent improvement in the public administration. Therefore, some countries may have designed their accountability regimes with different 
emphasis on the different dimensions of impacts of the audit information; for example, Denmark emphasising instrumental use in a principal-agent-type, hierarchical way. Therefore, we cannot rule out that type of performance audit, and the SAIs' choice of auditor role, may have impacts.

Another possible explanation for some of the different impacts between the countries is the fiscal situation. Denmark and countries such as Estonia were severely hit by the financial crisis in 2007 (Savi \& Randma-Liiv, 2015). The audits in these countries may have been used more as tools for checking economy and efficiency in public management reforms aiming for cutback management than in the other countries. For this reason, the audits may have been perceived as contributing to many changes but little improvement by many civil servants in Denmark, being the 'victims' for some of this information, during our period of analysis. Norway, by contrast, was - until the drop in crude oil prices in 2014 - largely sheltered from the most recent financial crisis, and the Norwegian government did not emphasise cutback management in the period of analysis.

\section{Conclusions}

The analysis across the four countries shows that the SAls' performance audits have positive impacts on perceived usefulness, changes, improvements, and, to some extent, accountability, at least in the context of the Nordic model of accountability regime. Important factors for conducting performance audits with positive impacts are SAls with much legitimacy, high quality in the audit report, avoiding rigidity, and communicating the performance audits to the wider society through media attention. Other factors that may determine impacts are the organisational design of central government institutions, such as decentralisation, and the main objectives of the performance audit, as well as fiscal factors such as cutback management in public policy.

The present study has relied to a large extent on previous research and research instruments. As with all empirical research, this study has certain limitations. First, as noted in the development of the conceptual model, there may be more complex relationships than mere linear processes between the determinants and the dimensions of impacts, as well as interdependencies between the dimensions of impact. Future research could develop the analysis by using, for instance, structural equation modelling instead of multiple regression, which we used. Second, we used survey data of civil servants in the auditees to explore the impacts of performance audit. This is just one source of data for impacts, and the survey data is moreover limited by the missing data problem. Furthermore, as the respondents were employed by the auditees that the auditors often had criticised, the responses could have had a bias towards understating the (positive) impacts of the audit. Although they are considered more reliable and valid for measuring impacts than asking audit staff or members of parliament, other sources such as administrative data for public administration changes and performance, may also be utilised in future studies. Third, the impact data that we have analysed spanned performance audits published in the years 2005-2012. Institutions and 
practices change, at least to some degree, so our results may have limited external validity over time and beyond the Nordic or Anglo-American accountability regime contexts.

These results have several implications for policy and practice. The analysis shows that SAIs' performance audits largely have positive impacts on public administration, as perceived by civil servants who have experienced the performance audits. Therefore, the underlying strategic choice of conducting performance audits, when the institutional arrangements are right, seems to be warranted. When it comes to the issue of how to conduct these performance audits for achieving high impact, this analysis provides some evidence on important design issues that policy makers and auditors need to consider, particularly legitimacy, quality, rigidity, and communication.

This analysis has revealed the need for more research. First, this article has explored the impact of SAls' performance audits on public administration in countries with relatively homogenous contexts (small, democratic, unitary high-trust countries); therefore, there is a need for more comparative impact studies from different institutional contexts. Second, this analysis was inconclusive with regards to the impact of the design of the performance audits and the orientation of the SAls. Consequently, there is a need for more studies of the impacts of different performance audits types (compliance, activity/accountability, and results oriented) and different SAI roles (judge, public accountant, evaluator, and consultant). Third, it would also be useful for future studies to distinguish between short-term and long-term impacts, between direct and indirect effects (deterrent effects), between small-scale and large-scale changes, and between symbolic and substantive steps taken in the audited organisations in response to the performance audits. 


\section{References}

Alford, J., Hartley, J., Yates, S., \& Hughes, O. (2017). Into the purple zone: Deconstructing the politics/administration distinction. American Review of Public Administration, 47, 752-763. doi.org/10.1177/0275074016638481

Barzelay, M. (1997). Central audit institutions and performance auditing: A comparative analysis of organizational strategies in the OECD. Governance, 10, 235-260. doi.org/10.1111/0952-1895.411997041

Basu, O.N., Dirsmith, M.W., \& Gupta, P.P. (1999). The coupling of the symbolic and the technical in an institutionalized context: The negotiated order of the GAO's audit reporting process. American Sociological Review, 64, 506-526. DOI: 10.2307/2657253

Blume, L., \& Voigt, S. (2007). Supreme audit institutions: supremely superfluous? A cross country assessment. ICER Working Paper No. 3/2007. Available at SSRN: http://ssrn.com/abstract=965434.

Boyne, G.A. (2003). What is public service improvement? Public Administration, 81, 211-227. doi.org/10.1111/1467-9299.00343

Bringselius, L. (2014). The dissemination of results from supreme audit institutions: Independent partners with the media? Financial Accountability and Management, 30, 7594. doi.org/10.1111/faam.12028

Brown, R.E., \& Craft, R. (1980). Auditing and public administration: The unrealized partnership. Public Administration Review, 40, 259-265. DOI: 10.2307/975380

Carrington, T., \& Catasús, B. (2007). Auditing stories about discomfort: Becoming comfortable with comfort theory. European Accounting Review, 16, 35-58. doi.org/10.1080/09638180701265846

Engeli, I., Allison, C.R., \& Montpetit, E. (2018). Beyond the usual suspects: New research themes in comparative public policy. Journal of Comparative Policy Analysis: Research and Practice, 20:1, 114-132. DOI: 10.1080/13876988.2017.1413869

Feldman, M.S., \& March, J.G. (1981). Information in organizations as signal and symbol. Administrative Science Quarterly, 26, 171-186. DOI: 10.2307/2392467

Fukuyama, F. (2015). Political order and political decay: From the industrial revolution to the globalization of democracy. Farrar, Straus and Giroux.

Funnell, W. (2015). Performance auditing and adjudicating political disputes. Financial Accountability and Management. 30, 92-111. doi.org/10.1111/faam.12046

Garrett, J. (1986). Developing state audit in Britain. Public Administration, 64, 421-433. doi.org/10.1111/j.1467-9299.1986.tb00633.x

George, B., and Pandey, S. K. (2017). We know the yin - but where is the yang? Toward a balanced approach on common source bias in public administration scholarship. Review of Public Personnel Administration, 37, 245-270. Doi: 10.1177/0734371X17698189

Glynn, J.J. (1985). Value for money auditing - an international review and comparison. Financial Accountability and Management, 1, 113-128. doi.org/10.1111/j.14680408.1985.tb00248.x 
González-Díaz, B., García-Fernández, R., \& López-Díaz, A. (2013). Communication as a transparency and accountability strategy in supreme audit institutions. Administration and Society, 45, 583-609. DOI: 10.1177/0095399712438376

Guthrie, J.E., \& Parker, L.D. (1999). A quarter of a century of performance auditing in the Australian federal public sector: A malleable masque. Abacus, 35, 302-332. doi.org/10.1111/1467-6281.00048

Hair jr., J.F., Anderson, R.E., Tatham, R.L., \& Black, W.C. (1992). Multivariate data analysis. 3rd edition. New York: Macmillan.

Hood, C. (1995). The new public management in the 1980s: Variations on a theme. Accounting, Organizations and Society. 20, 2/3, 93-109. doi.org/10.1016/0361-3682(93)E0001-W

Hood, C. (1998). The art of the state: Culture, rhetoric, and public management. London: Clarendon Press.

Hood, C. (2007). What happens when transparency meets blame-avoidance? Public Management Review, 9, 191-210. doi.org/10.1080/14719030701340275

Huber, G.P. (1991). Organizational learning: The contributing processes and the literatures. Organization Science, 2, 88-115. doi.org/10.1287/orsc.2.1.88

ISSAI 3000. Standards for performance auditing. INTOSAI Professional Standards Committee. Copenhagen: Riksrevisionen.

ISSAI 3200. Guidelines for the performance auditing process. INTOSAI Professional Standards Committee. Copenhagen: Riksrevisionen.

Jacobs, K. (1998). Value for money auditing in New Zealand: Competing for control in the public sector. British Accounting Review, 30, 343-360. doi.org/10.1006/bare.1998.0077

Jakobsen, M., \& Jensen, R. (2015). Common method bias in public management studies. International Public Management Journal, 18, 3-30. DOI: 10.1080/10967494.2014.997906

Jeppesen, K.K., Carrington, T., Catasus, B., Johnsen, Å., Reichborn-Kjennerud, K., \& Vakkuri, J. (2017). The strategic options of supreme audit institutions: The case of four Nordic countries. Financial Accountability \& Management, 32, 146-170. doi.org/10.1111/faam.12118

Jones, B.D., \& Baumgartner, F.R. (2005). The politics of attention: How government prioritizes problems. Chicago: Chicago University Press.

Keen, J. (1999). On the nature of audit judgements: The case of value for money studies. Public Administration, 77, 509-525. doi.org/10.1111/1467-9299.00165

Lægreid, P. (2014). Accountability and the new public management. In M. Bovens, R.E. Bovens, M., Goodin, R.E., \& Schillemans, T. (Eds.), The Oxford handbook of public accountability (pp. 324-338). Oxford: Oxford University Press.

Lapsley, I. (2009). New public management: The cruellest invention of the human spirit? Abacus, 45, 1-21. doi.org/10.1111/j.1467-6281.2009.00275.x

Lonsdale, J. (2000). Developments in value-for-money audit methods: Impacts and implications. International Review of Administrative Sciences, 66, 73-89. doi.org/10.1177/0020852300661007 
Lonsdale, J. (2008). Balancing independence and responsiveness: A practitioner perspective on the relationships shaping performance audit. Evaluation, 14, 227-248. DOI: 10.1177/1356389007087541

McCubbins, M.D., \& Schwartz, T. (1984). Congressional oversight overlooked: Police patrols versus fire alarms. American Journal of Political Science, 28, 165-179. DOI: $10.2307 / 2110792$

Meier, K.J., Winter, S.C. O'Toole, L.J. Jr., Favero, N., \& Andersen, S.C. (2015). The validity of subjective performance measures: School principals in Texas and Denmark. Public Administration, 93, 1084-1101. doi.org/10.1111/padm.12180

Metcalfe, L., \& Richards, S. (1990). Improving public management. 2nd ed. London: Sage.

Moe, T.M. (1997). The positive theory of public bureaucracy. In D.C. Mueller, (Ed.), Perspectives on public choice (pp. 455-480). Cambridge: Cambridge University Press.

Morin, D. (2001). Influence of value for money audit on public administrations: Looking beyond appearances. Financial Accountability and Management, 17, 99-117. https://doi.org/10.1111/1468-0408.00123

Morin, D. (2010). Welcome to the court. International Review of Administrative Sciences, 76, 25-46. doi.org/10.1177/0020852309359043

Morin, D. (2014). Auditors General's impact on administrations: A pan-Canadian study (20012011). Managerial Auditing Journal, 29, 395-426. doi.org/10.1108/MAJ-10-2013-0948

Nutley, S.M., \& Webb, J. (2000). Evidence and the policy process. In H.T.O. Davies, S.M. Nutley, \& P.C. Smith (Eds.), What works? Evidence-based policy and practice in public services (pp. 13-41). Bristol: The Policy Press.

Öberg, S.A., \& Wockelberg, H. (2016). Nordic administrative heritages and contemporary institutional design. In C. Greve, P. Lægreid, \& L.H. Rykkja (Eds.), Nordic administrative reforms: Lessons for public management (pp. 57-78). Basingstoke: Palgrave Macmillan.

Osborne, S.P. (2006). The new public governance?. Public Management Review, 8, 377-387. DOI: $10.1080 / 14719030600853022$

Pollitt, C., \& Bouckaert, G. (2011). Public management reform: A comparative analysis. 3rd ed. Oxford: Oxford University Press.

Pollitt, C., Girre, X., Lonsdale, J., Mul, R., Summa, H., \& Waerness, M. (1999). Performance or compliance? Performance audit and public management in five countries. Oxford: Oxford University Press.

Power, M. (1996). Making things auditable. Accounting, Organizations and Society, 21, 289315. doi.org/10.1016/0361-3682(95)00004-6

Power, M. (1997). The audit society: Rituals of verification. Oxford: Oxford University Press.

Power, M. (2003). Evaluating the audit explosion. Law and Policy, 25, 185-202. doi.org/10.1111/j.1467-9930.2003.00147.x

Put, V., \& Bouckaert, G. (2011). Managing performance and auditing performance. In T. Christensen, \& P. Lægreid (Eds.), The Ashgate research companion to new public management (pp. 223-236). Farnham: Ashgate. 
Raudla, R., Taro, K., Agu, C., \& Douglas, J.W. (2016). The impact of performance audit on public sector organizations: The case of Estonia. Public Organization Review, 16, 217-233. Doi:10.1007/s11115-015-0308-0

Reichborn-Kjennerud, K. (2013). Political accountability and performance audit: The case of the Auditor General in Norway. Public Administration, 91, 680-695. doi.org/10.1111/padm.12025

Reichborn-Kjennerud, K. (2014). Performance audit and the importance of the public debate. Evaluation, 20, 368-385. doi.org/10.1177/1356389014539869

Reichborn-Kjennerud, K., \& Johnsen, Å. (2011). Auditors' understanding of evidence: A performance audit of an urban development programme. Evaluation, 17, 217-231. doi.org/10.1177/1356389011410523

Reichborn-Kjennerud, K., \& Johnsen, Å. (2018). Performance audit and supreme audit institutions' impact on public administration: The case of the Office of the Auditor General in Norway. Administration \& Society, 50, 1422-1446. Doi: 10.1177/0095399715623315

Richardson, J., \& Kindblad, B.M. (1983). Programme evaluation and effectiveness auditing in Sweden: The changing Swedish policy style. Scandinavian Political Studies, 6, 75-98. doi.org/10.1111/j.1467-9477.1983.tb00271.x

Roberts, S. \& Pollitt, C. (1994). Audit or evaluation? A National Audit Office VFM study. Public Administration, 72, 527-549. doi.org/10.1111/j.1467-9299.1994.tb00807.x

Rothstein, B. (2011). The quality of government: Corruption, social trust, and inequality in international perspective. Chicago: University of Chicago Press.

Savi, R., \& Randma-Liiv, T. (2015). Decision-making in time of crisis: Cutback management in Estonia. International Review of Administrative Sciences, 81, 479-497. doi.org/10.1177/0020852315573131

Skærbæk, P. (2009). Public sector auditor identities in making efficiency auditable: The National Audit Office of Denmark as independent auditor and modernizer. Accounting, Organizations and Society, 34, 971-987. doi.org/10.1016/j.aos.2009.01.001

Skærbæk, P., \& Christensen, M. (2015). Auditing and the purification of blame. Contemporary Accounting Research, 32, 1263-1284. doi.org/10.1111/1911-3846.12106

Streim, H. (1994). Agency problems in the legal political system and supreme audit institutions. European Journal of Law and Economics, 1, 177-191. doi.org/10.1007/BF01552469

Torres, L., Yetano, A., \& Pina, V. (2016). Are performance audits useful? A comparison of EU practices. Administration \& Society. Published online 7.7.2016. Doi: 10.1177/0095399716658500

Triantafillou P. (2017). Playing a zero-sum game? The pursuit of independence and relevance in performance auditing. Public Administration, 1-15. Published online 12.11.2017. doi.org/10.1111/padm.12377

Van Loocke, E., \& Put, V. (2011). The impact of performance audits: A review of the existing evidence. In J. Lonsdale, P. Wilkins, \& T. Ling (Eds.), Performance auditing: Contributing to accountability in democratic government (pp. 175-208). Cheltenham: Edward Elgar. 
Van Thiel, S. (2014). Research methods in public administration. London: Routledge.

Weiss, C.H. (1979). The many meanings of research utilization. Public Administration Review, $39,426-431$.

White, F., \& Hollingsworth, K. (1999). Audit, accountability and government. Oxford: Clarendon Press.

Wilson, J.Q. (2000). Bureaucracy: What government agencies do and why they do it. 2nd ed. New York: Basic Books. 
Figure 1 Conceptual framework

$\mathrm{H} 1+$

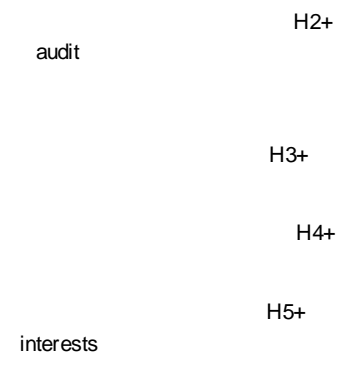

$\mathrm{H} 6$

$\mathrm{H} 7+$

H8-

$\mathrm{H} 9+$

communication

H10+ $\mathrm{H} 11+$

H13+

$\mathrm{H} 12+$

Table 1 Demografic, economic and institutional factors in the four countries

\begin{tabular}{llllll}
\hline \hline & $\begin{array}{l}\text { Population in } \\
\text { millions, 2012* }\end{array}$ & $\begin{array}{l}\text { Mean percentage } \\
\text { annual change in } \\
\text { GDP 2005-2014 }\end{array}$ & $\begin{array}{l}\text { GDP per } \\
\text { capita 2014, } \\
\text { USD }\end{array}$ & $\begin{array}{l}\text { National Audit } \\
\text { established }\end{array}$ & SAl established \\
Denmark & 5.6 & 0.2 & 60,634 & 1849 & 1991 \\
Finland & 5.4 & 0.7 & 49,541 & 1824 & 2001 \\
Norway & 5.0 & 1.4 & 97,363 & 1816 & 1918 \\
Sweden & 9.5 & 1.7 & 58,887 & 1961 & 2003 \\
\hline \hline
\end{tabular}

Note: * Source: OECD. ${ }^{* *}$ Source: World Bank.

Table 2 Responses from the four countries

\begin{tabular}{lrrrr}
\hline \hline & Period of study & Targeted sample & Responding sample & Response rate \\
Denmark & $2005-2012$ & 140 & 127 & $91 \%$ \\
Finland & $2005-2012$ & 413 & 64 & $15 \%$ \\
Norway & $2005-2010$ & 471 & 336 & $71 \%$ \\
Sweden & $2005-2012$ & 178 & 116 & $65 \%$ \\
Total & & 643 & $53 \%$ \\
\hline \hline
\end{tabular}




\begin{tabular}{|c|c|c|c|}
\hline & $\begin{array}{c}\text { Survey } \\
\text { question }\end{array}$ & $\begin{array}{c}\text { Reliability } \\
\text { (Cronbach } \\
\text { alpha) }\end{array}$ & $\mathbf{N}$ \\
\hline SAl legitimacy index & & 0.73 & 597 \\
\hline $\begin{array}{l}\text { The performance audits of the SAI are contributing to improvements in the audited } \\
\text { entities }\end{array}$ & Q11 & & \\
\hline The SAI is an important institution that promotes transparency and prevents fraud & Q11a & & \\
\hline Performance audit rigidity index & & 0.64 & 399 \\
\hline $\begin{array}{l}\text { The performance audit report shows that the auditors have zero tolerance for deviance } \\
\text { in results from the objectives that have been set }\end{array}$ & Q22C & & \\
\hline $\begin{array}{l}\text { The performance audit report recommended additional controls without considering } \\
\text { whether the increase in costs would pay off in reduced risk }\end{array}$ & Q22f & & \\
\hline $\begin{array}{l}\text { The conclusions in the performance audit report appeared oversimplified by failing to } \\
\text { distinguish between more and less important audit evidence }\end{array}$ & Q22h & & \\
\hline The SAl's focus makes the auditors always find something to criticize & Q22j & & \\
\hline Audit process strain index & & 0.83 & 366 \\
\hline $\begin{array}{l}\text { More controls and thereby more work have come as a consequence of the } \\
\text { performance audit }\end{array}$ & Q29a & & \\
\hline $\begin{array}{l}\text { In relation to partners, the media, customers and clients, we notice that the reputation } \\
\text { of our workplace has deteriorated }\end{array}$ & Q29b & & \\
\hline We have seen an increase in cost and use of resources after the performance audit & Q29c & & \\
\hline It is harder for management to prioritise as the performance audit sets the agenda & Q29g & & \\
\hline $\begin{array}{l}\text { The SAl's use of government financial regulations in the audit criteria led to overly } \\
\text { detailed control }\end{array}$ & Q29h & & \\
\hline Audit process communication index & & 0.94 & 266 \\
\hline Our comments regarding our risk assessment were sufficiently taken into account & Q19 & & \\
\hline Our comments regarding the audit questions were sufficiently taken into account & Q19a & & \\
\hline Our comments regarding the audit criteria were sufficiently taken into account & Q19b & & \\
\hline $\begin{array}{l}\text { Our comments regarding the meeting minutes from interviews were sufficiently taken into } \\
\text { account }\end{array}$ & Q19c & & \\
\hline Our comments given during contact meetings were sufficiently taken into account & Q19d & & \\
\hline $\begin{array}{l}\text { Our comments regarding the audit evidence (factual basis) were sufficiently taken into } \\
\text { account }\end{array}$ & Q19e & & \\
\hline $\begin{array}{l}\text { Our comments regarding the SAl's interpretation of the audit evidence were sufficiently } \\
\text { taken into account }\end{array}$ & Q19f & & \\
\hline Our comments regarding the SAl's assessments were sufficiently taken into account & Q19g & & \\
\hline Audit report quality index & & 0.88 & 418 \\
\hline The use of methods in the performance audit held scientific/good standards & Q22 & & \\
\hline The performance audit report held good quality & Q22a & & \\
\hline The performance audit report dealt with some of our more important policy areas & Q22b & & \\
\hline Most of the conclusions in the performance audit report were sufficiently concrete & Q22d & & \\
\hline $\begin{array}{l}\text { The performance audit report took sufficiently into account the fact that we have to meet } \\
\text { several conflicting objectives }\end{array}$ & Q22e & & \\
\hline The performance audit report was an important source of information for me in my work & Q22g & & \\
\hline The performance audit report proved that the auditors had good sector expertise & Q22i & & \\
\hline $\begin{array}{l}\text { The link between audit criteria, facts and assessments in the performance audit report } \\
\text { was clear }\end{array}$ & Q22k & & \\
\hline Consequences of media attention index & & 0.81 & 389 \\
\hline $\begin{array}{l}\text { The audited entity became overly prudent in their management practices in light of the } \\
\text { information reported in the media }\end{array}$ & Q32 & & \\
\hline The reputation of the audited entity was affected & Q32a & & \\
\hline A political debate was launched & Q32b & & \\
\hline The minister and/or the administration were put under pressure from political opponents & Q32C & & \\
\hline Improvement index & & 0.67 & 475 \\
\hline $\begin{array}{l}\text { Policy areas that did not receive much attention before have been given priority after the } \\
\text { performance audit }\end{array}$ & Q29e & & \\
\hline We have made changes to systems that previously did not work very well & Q29f & & \\
\hline
\end{tabular}


Table 4 Descriptive statistics and correlation analysis (Pearson). ( $\mathrm{N}=167)$

\begin{tabular}{|c|c|c|c|c|c|c|c|c|c|c|c|c|c|c|c|c|c|c|c|c|c|c|c|c|}
\hline & 1 & 2 & 3 & 4 & 5 & 6 & 7 & 8 & 9 & 10 & 11 & 12 & 13 & 14 & 15 & 16 & 17 & 18 & 19 & 20 & 21 & 22 & 23 & 24 \\
\hline 1 Usefulness & & & & & & & & & & & & & & & & & & & & & & & & \\
\hline 2 Holding to account & .11 & & & & & & & & & & & & & & & & & & & & & & & \\
\hline 3 Change & $.35^{* *}$ & .06 & & & & & & & & & & & & & & & & & & & & & & \\
\hline 4 Improvement & $.52^{\star *}$ & $.24^{* *}$ & $.32^{* *}$ & & & & & & & & & & & & & & & & & & & & & \\
\hline 5 SAI legitimacy Index & $.67^{* \star}$ & .05 & $.24^{\star \star}$ & $.46^{\star \star}$ & & & & & & & & & & & & & & & & & & & & \\
\hline $\begin{array}{l}6 \text { Activity-oriented } \\
\text { audit }\end{array}$ & -.15 & -.04 & .12 & -.01 & -.11 & & & & & & & & & & & & & & & & & & & \\
\hline $\begin{array}{l}7 \text { Compliance-oriented } \\
\text { audit }\end{array}$ & -.08 & -.09 & -.03 & -.09 & -.07 & $-{ }^{-} .40^{\star *}$ & & & & & & & & & & & & & & & & & & \\
\hline $\begin{array}{l}8 \text { Results-oriented } \\
\text { audit }\end{array}$ & $.20^{* *}$ & .12 & -.06 & .10 & $.16^{*}$ & $\begin{array}{l}- \\
.38^{* *}\end{array}$ & $\begin{array}{l}- \\
.70^{\star *}\end{array}$ & & & & & & & & & & & & & & & & & \\
\hline 9 Administrative level & -.04 & .01 & .07 & -.01 & .11 & $-.15^{\star}$ & .11 & .01 & & & & & & & & & & & & & & & & \\
\hline $\begin{array}{l}10 \text { Actors furthering } \\
\text { own interests }\end{array}$ & -.06 & .15 & .03 & .01 & -.05 & .10 & -.04 & -.04 & -.07 & & & & & & & & & & & & & & & \\
\hline $\begin{array}{l}11 \text { Supporting existing } \\
\text { plans }\end{array}$ & $.24^{\star \star}$ & .03 & .11 & $.192^{*}$ & $.20^{\star \star}$ & .01 & -.10 & .09 & -.01 & -.09 & & & & & & & & & & & & & & \\
\hline 12 Audit rigidity Index & $\begin{array}{l}- \\
.33^{* *}\end{array}$ & .01 & .13 & -.12 & $\begin{array}{l}- \\
.29 * *\end{array}$ & .11 & .07 & -.15 & -.01 & .11 & -.08 & & & & & & & & & & & & & \\
\hline $\begin{array}{l}13 \text { Audit process } \\
\text { strain Index }\end{array}$ & $\begin{array}{l}- \\
.30^{\star *}\end{array}$ & .14 & $.16^{\star}$ & -.08 & $\begin{array}{l}- \\
.29 * *\end{array}$ & .15 & .10 & $\begin{array}{l}- \\
.21^{* *}\end{array}$ & -.06 & $.45^{\star *}$ & $\begin{array}{l}- \\
.25^{* *}\end{array}$ & $.45^{\star *}$ & & & & & & & & & & & & \\
\hline $\begin{array}{l}14 \text { Audit process } \\
\text { communication Index }\end{array}$ & $.54^{\star *}$ & .07 & .13 & $.34^{* *}$ & $.52^{\star *}$ & $-.18^{\star}$ & -.03 & $.17^{*}$ & $.15^{*}$ & -.04 & $.35^{* *}$ & $\begin{array}{l}- \\
.39 * *\end{array}$ & $\begin{array}{l}- \\
.36^{* *}\end{array}$ & & & & & & & & & & & \\
\hline $\begin{array}{l}15 \text { Audit report quality } \\
\text { Index }\end{array}$ & $.71^{* *}$ & .10 & $.27^{* *}$ & $.42^{\star *}$ & $.65^{\star *}$ & -.10 & -.08 & $.16^{*}$ & .01 & -.04 & $.37^{* *}$ & $\begin{array}{l}- \\
.28^{* *}\end{array}$ & $\begin{array}{l}- \\
.32^{* *}\end{array}$ & $.76^{* *}$ & & & & & & & & & & \\
\hline 16 Media attention & .00 & .15 & .10 & .00 & -.04 & $.20^{\star \star}$ & $-.16^{\star}$ & .00 & -.03 & $.37^{\star \star}$ & -.13 & .07 & $.33^{\star *}$ & $-.19 *$ & -.06 & & & & & & & & & \\
\hline
\end{tabular}




\begin{tabular}{|c|c|c|c|c|c|c|c|c|c|c|c|c|c|c|c|c|c|c|c|c|c|c|c|c|}
\hline $\begin{array}{l}17 \text { Consequences of } \\
\text { media attention index }\end{array}$ & $-.15^{\star}$ & $.23^{\star \star}$ & .12 & -.12 & $-.16^{\star}$ & .14 & -.07 & -.04 & .02 & $.44^{\star *}$ & $\begin{array}{l}- \\
.27^{* *}\end{array}$ & $.26^{* *}$ & $.56^{\star *}$ & $-31^{* *}$ & $\begin{array}{l}- \\
.23^{\star *}\end{array}$ & $.66^{* \star}$ & & & & & & & & \\
\hline 18 Improvement index & $.55^{* \star}$ & .15 & $.44^{\star \star}$ & $.44^{\star \star}$ & $.43^{* *}$ & -.02 & .04 & -.02 & -.01 & .14 & .10 & -.06 & .14 & $.32^{* *}$ & $.45^{\star *}$ & .15 & .12 & & & & & & & \\
\hline $\begin{array}{l}19 \text { Management } \\
\text { position }\end{array}$ & .15 & .06 & -.07 & .05 & .08 & -.02 & -.07 & .09 & $-30^{\star *}$ & -.01 & -.11 & -.07 & -.14 & -.04 & .08 & -.05 & -.08 & -.06 & & & & & & \\
\hline $\begin{array}{l}20 \text { Performance } \\
\text { audit experience }\end{array}$ & .04 & .12 & .12 & .04 & -.05 & -.09 & .05 & .02 & -.14 & .02 & .03 & .09 & $.16^{\star}$ & -.04 & .00 & $.19^{\star}$ & .04 & .10 & -.05 & & & & & \\
\hline 21 Denmark & $\begin{array}{l}- \\
.28^{\star \star}\end{array}$ & $-.16^{\star}$ & -.03 & $-.19^{*}$ & $-\overline{-}^{-} \cdot 2^{* *}$ & .10 & .10 & $-.18^{*}$ & .14 & -.10 & $-.19 *$ & .13 & $.21^{\star *}$ & -.12 & $\begin{array}{l}- \\
.22^{\star *}\end{array}$ & -.08 & .00 & .03 & $\begin{array}{l}- \\
.29^{* \star}\end{array}$ & .03 & & & & \\
\hline 22 Finland & $.22^{\star \star}$ & .10 & .00 & -.07 & .11 & -.11 & .05 & .03 & $-22^{* *}$ & .05 & .05 & $-.16^{*}$ & $-.15^{*}$ & .06 & $.20^{\star *}$ & -.10 & -.02 & .04 & .09 & -.03 & $-49^{* *}$ & & & \\
\hline 23 Norway & .00 & -.03 & .14 & $.22^{* *}$ & .02 & .11 & $-.15^{*}$ & .07 & -.06 & .05 & .14 & $.167^{\star}$ & .11 & -.02 & .00 & $.27^{\star \star}$ & $.16^{*}$ & .08 & .02 & .08 & $\begin{array}{l}- \\
.34^{\star *}\end{array}$ & $\begin{array}{l}- \\
.44^{* *}\end{array}$ & & \\
\hline 24 Sweden & .05 & .11 & -.14 & .08 & .12 & -.11 & -.02 & .11 & $.23^{* *}$ & -.01 & .01 & $-.16^{*}$ & $\begin{array}{l}- \\
.20^{\star *}\end{array}$ & .10 & .01 & -.10 & $-.18^{\star}$ & $\begin{array}{l}- \\
.22^{\star \star}\end{array}$ & $.25^{\star \star}$ & -.10 & $\begin{array}{l}- \\
.21^{\star *}\end{array}$ & $\begin{array}{l}- \\
.27^{* *}\end{array}$ & $-.19 *$ & \\
\hline $\begin{array}{l}\text { Mean } \\
\text { Standard deviation }\end{array}$ & $\begin{array}{l}3.28 \\
1.074\end{array}$ & $\begin{array}{l}2.69 \\
1150\end{array}$ & $\begin{array}{l}3.22 \\
0.947\end{array}$ & $\begin{array}{l}3.08 \\
1061\end{array}$ & $\begin{array}{l}3.63 \\
0.898\end{array}$ & 0.18 & 0.42 & 0.40 & 0.56 & $\begin{array}{l}2.93 \\
1269\end{array}$ & $\begin{array}{l}3.31 \\
0.936\end{array}$ & $\begin{array}{l}3.19 \\
0.741\end{array}$ & $\begin{array}{l}2.41 \\
0.932\end{array}$ & $\begin{array}{l}3.20 \\
0.841\end{array}$ & $\begin{array}{l}3.19 \\
0.67\end{array}$ & $\begin{array}{l}2.60 \\
1317\end{array}$ & $\begin{array}{l}2.07 \\
0.946\end{array}$ & $\begin{array}{l}2.93 \\
0.904\end{array}$ & $\begin{array}{l}2.00 \\
0.850\end{array}$ & $\begin{array}{l}3.57 \\
4059\end{array}$ & 0.28 & 0.38 & 0.23 & 0.11 \\
\hline $\begin{array}{l}\text { Standard deviation } \\
\text { Variable range }\end{array}$ & $\begin{array}{l}1.074 \\
1-5\end{array}$ & $\begin{array}{l}1.150 \\
1-5\end{array}$ & $\begin{array}{l}0.947 \\
1-5\end{array}$ & $\begin{array}{l}1.061 \\
1-5\end{array}$ & $\begin{array}{l}0.898 \\
1-5\end{array}$ & $0-1$ & $0-1$ & $0-1$ & $0-1$ & $\begin{array}{l}1.269 \\
1-5\end{array}$ & $\begin{array}{l}0.936 \\
1-5\end{array}$ & $\begin{array}{l}0.741 \\
1-5\end{array}$ & $\begin{array}{l}0.932 \\
1-5\end{array}$ & $\begin{array}{l}0.841 \\
1-5\end{array}$ & $1-5$ & $1-5$ & $1-5$ & $1-5$ & $1-3$ & $0-31$ & $0-1$ & $0-1$ & $0-1$ & $0-1$ \\
\hline
\end{tabular}

Note: ${ }^{* *}=$ significant at the 0.01 level, ${ }^{*}=$ significant at the 0.05 level (two-tailed). 
Table 5 Multiple regression analysis of impacts of performance audit on public administration

\begin{tabular}{|c|c|c|c|c|c|c|c|c|c|c|c|c|c|c|c|c|}
\hline & \multicolumn{4}{|c|}{ Usefulness $(\mathrm{N}=194)$} & \multicolumn{4}{|c|}{ Accountability $(\mathrm{N}=174)$} & \multicolumn{4}{|c|}{ Change (N=172) } & \multicolumn{4}{|c|}{ Improvement (N=172) } \\
\hline & \multicolumn{2}{|c|}{ Modell I } & \multicolumn{2}{|c|}{ Modell II } & \multicolumn{2}{|c|}{ Modell III } & \multicolumn{2}{|c|}{ Modell IV } & \multicolumn{2}{|c|}{ Modell V } & \multicolumn{2}{|c|}{ Modell VI } & \multicolumn{2}{|c|}{ Modell VII } & \multicolumn{2}{|c|}{ Modell VIII } \\
\hline & $B$ & Sign. & $B$ & Sign. & $B$ & Sign. & $B$ & Sign. & $B$ & Sign. & $B$ & Sign. & $B$ & Sign. & $B$ & Sign. \\
\hline Constant & .11 & .809 & .08 & .872 & .70 & .385 & .60 & .490 & .60 & .371 & .81 & .274 & .17 & .816 & 1.12 & .159 \\
\hline SAl legitimacy index & $.33^{\star *}$ & .000 & $.32^{\star *}$ & .000 & -.03 & .796 & -.06 & .632 & $.17+$ & .082 & $.17+$ & .087 & $.40^{* *}$ & .000 & $.36^{* *}$ & .001 \\
\hline Activity-oriented audit & .09 & .505 & .03 & .822 & -.03 & .907 & -.08 & .752 & $-.33+$ & .096 & -.32 & .102 & -.14 & .521 & -.07 & .759 \\
\hline Results-oriented audit & .21 & .117 & .16 & .227 & .20 & .419 & .14 & .579 & $-.38+$ & .056 & $-.38+$ & .058 & -.03 & .900 & -.02 & .938 \\
\hline Administrative level & -.07 & .476 & -.08 & .441 & .07 & .698 & .01 & .951 & .17 & .260 & .22 & .159 & -.05 & .762 & -.12 & .485 \\
\hline Actors furthering their own interests & & & & & .03 & .672 & -.01 & .941 & .07 & .386 & .06 & .473 & .08 & .348 & .05 & .606 \\
\hline Supported existing plans & -.01 & .894 & -.01 & .822 & & & & & -.07 & .245 & -.07 & .313 & .00 & .957 & .02 & .820 \\
\hline Audit rigidity index & $-.17^{*}$ & .019 & $-.15^{\star}$ & .043 & -.05 & .727 & .00 & .985 & .12 & .245 & .10 & .341 & -.02 & .879 & -.08 & .493 \\
\hline Audit process strain index & -.10 & .137 & -.09 & .186 & .09 & .516 & .14 & .284 & $.21^{*}$ & .047 & $.21+$ & .058 & .18 & .125 & .16 & .160 \\
\hline Audit process communication index & -.07 & .478 & -.05 & .571 & .14 & .423 & .16 & .347 & -.06 & .683 & -.05 & .713 & .10 & .493 & .03 & .821 \\
\hline Audit report quality index & $.49^{* *}$ & .000 & $.47^{\star *}$ & .000 & .14 & .482 & .13 & .504 & $.38^{*}$ & .016 & $.37^{\star}$ & .025 & .18 & .304 & .27 & .122 \\
\hline Media attention & & & & & -.05 & .576 & -.04 & .680 & -.04 & .626 & -.04 & .560 & .04 & .657 & -.03 & .749 \\
\hline Consequences of media attention index & & & & & $.37^{*}$ & .011 & $.38^{* *}$ & .009 & .13 & .249 & .12 & .318 & -.10 & .430 & -.07 & .584 \\
\hline Improvement index & $.35^{\star *}$ & .000 & $.38^{\star *}$ & .000 & & & & & & & & & & & & \\
\hline Management position & $.13^{*}$ & .034 & .08 & .193 & .12 & .262 & .04 & .746 & -.02 & .820 & .01 & .953 & .05 & .585 & .00 & .970 \\
\hline Performance audit experience & .01 & .277 & .01 & .233 & .03 & .153 & .03 & .126 & .03 & .138 & .03 & .146 & .01 & .710 & .01 & .690 \\
\hline Denmark & & & -.08 & .558 & & & -.11 & .666 & & & -.14 & .502 & & & $-.48^{*}$ & .027 \\
\hline Finland & & & .18 & .157 & & & .28 & .232 & & & -.11 & .561 & & & $-.61^{\star \star}$ & .004 \\
\hline Sweden & & & $.31+$ & .081 & & & $.72^{*}$ & .034 & & & -.36 & .186 & & & -.21 & .472 \\
\hline F-value & 29.880 & .000 & 24.790 & .000 & 1.851 & .040 & 2.004 & .016 & 3.130 & .000 & 2.008 & .001 & 3.921 & .000 & 3.946 & .000 \\
\hline Adjusted R2 & .64 & & .65 & & .06 & & .09 & & .15 & & .14 & & .19 & & .23 & \\
\hline Highest Variance Inflation Index (VIF) & 3.612 & & 3.389 & & 3.036 & & 3.596 & & 3.336 & & 3.555 & & 3.424 & & 3.635 & \\
\hline
\end{tabular}




\begin{tabular}{|c|c|c|c|}
\hline \multirow[t]{2}{*}{ Hypothesis } & \multicolumn{3}{|c|}{ Corroboraton } \\
\hline & Earlier stud & & This study \\
\hline $\begin{array}{l}\text { H1: Performance audits conducted by SAls that are } \\
\text { perceived as having much legitimacy are perceived as } \\
\text { more useful than performance audits conducted by SAls } \\
\text { that are perceived as having little legitimacy. }\end{array}$ & $\begin{array}{l}\text { Reichborn-Kjennerud } \\
\text { (2013) H2 }\end{array}$ & Yes & Yes \\
\hline $\begin{array}{l}\text { H2: Results-oriented audits will be perceived as more } \\
\text { useful for the auditees than activity- and compliance- } \\
\text { oriented audits }\end{array}$ & & & No \\
\hline $\begin{array}{l}\text { H3: Civil servants in subordinate bodies will perceive } \\
\text { performance audits as more useful than will civil servants } \\
\text { in ministries. }\end{array}$ & & & No \\
\hline $\begin{array}{l}\text { H4: Subordinate bodies will use the performance audits } \\
\text { more for making changes than ministries will. }\end{array}$ & $\begin{array}{c}\text { Reichborn-Kjennerud \& } \\
\text { Johnsen (2018) H5 }\end{array}$ & Yes & No \\
\hline $\begin{array}{l}\text { H5: Performance audits used by different actors to further } \\
\text { their interests are used more for holding someone to } \\
\text { account than performance audits that are not used by } \\
\text { different actors to further their interests. }\end{array}$ & & & No \\
\hline $\begin{array}{l}\text { H6: Performance audit conclusions that conform to the } \\
\text { auditees' existing plans for making changes prior to the } \\
\text { audits are used more for making changes than } \\
\text { performance audits that do not conform to prior plans. }\end{array}$ & $\begin{array}{l}\text { Reichborn-Kjennerud \& } \\
\text { Johnsen (2018) H6 }\end{array}$ & Yes & No \\
\hline $\begin{array}{l}\text { H7: Performance audits that are rigid are less useful than } \\
\text { performance audits that are less rigid. }\end{array}$ & & & No \\
\hline $\begin{array}{l}\text { H8: Performance audits that put little strain on the auditees } \\
\text { are perceived as more useful than performance audits that } \\
\text { put a lot of strain on the auditees. }\end{array}$ & & & No \\
\hline $\begin{array}{l}\text { H9: Performance audits with good communication } \\
\text { between the SAls and the auditees are used more for } \\
\text { changes than performance audits with poor } \\
\text { communication. }\end{array}$ & $\begin{array}{l}\text { Reichborn-Kjennerud } \\
\text { (2013) H11 }\end{array}$ & Yes & No \\
\hline $\begin{array}{l}\text { H10: Performance audits that are perceived as having high } \\
\text { quality are perceived more useful than performance audits } \\
\text { that are perceived as having low quality. }\end{array}$ & $\begin{array}{c}\text { Reichborn-Kjennerud } \\
\text { (2013) H3 } \\
\text { Raudla et al. (2016) H2.2 }\end{array}$ & $\begin{array}{l}\text { Yes } \\
\text { Yes }\end{array}$ & Yes \\
\hline $\begin{array}{l}\text { H11: Performance audits that are perceived as having high } \\
\text { quality are used more for making changes than } \\
\text { performance audits that are perceived as having low } \\
\text { quality. }\end{array}$ & Raudla et al. (2016) H3.2 & Yes & Yes \\
\hline $\begin{array}{l}\text { H12: Performance audits that are subject to much media } \\
\text { interest are used more for holding someone to account } \\
\text { than performance audit subject to little media interest. }\end{array}$ & $\begin{array}{l}\text { Reichborn-Kjennerud } \\
\text { (2013) H9 }\end{array}$ & Yes & Partial \\
\hline $\begin{array}{l}\text { H13: Performance audits that are subject to much media } \\
\text { interest are used more for making changes than } \\
\text { performance audits subjected to little media interest. }\end{array}$ & Raudla et al. (2016) H3.7 & Partial & No \\
\hline
\end{tabular}

